\title{
Outdoor Environmental Radiation Monitoring and Estimation of Radiation Risk on Public in New Market Thana, Dhaka, Bangladesh
}

\author{
I. K. Sumi ${ }^{1}$, M. S. Rahman ${ }^{2 *}$, K. N. Sakib ${ }^{1}$, M. M. Tasnim ${ }^{1}$, S. Yeasmin ${ }^{2}$ \\ ${ }^{1}$ Department of Physics, Mawlana Bhashani Science and Technology University, Santosh, Tangail- \\ 1902, Bangladesh \\ ${ }^{2}$ Health Physics Division, Atomic Energy Centre, 4 Kazi Nazrul Islam Avenue, Shahbag, Dhaka- \\ 1000, Bangladesh
}

Received 22 April 2021, accepted in final revised form 25 June 2021

\begin{abstract}
The Real-time outdoor environmental gamma radiation (RTOEGR) dose rates were monitored at New Market Thana in Dhaka city to generate a baseline database that would help to know any deviation after operation of Rooppur NPP. The RTOEGR monitoring was carried out using a digital portable radiation monitoring device (DPRMD). The RTOEGR dose rates at the area of New Market Thana were ranged from $0.103 \pm 0.004 \mu \mathrm{Sv} / \mathrm{h}$ to 0.168 $\pm 0.007 \mu \mathrm{Sv} / \mathrm{h}$ with an average of $0.135 \pm 0.004 \mu \mathrm{Sv} / \mathrm{h}$. The public's annual effective doses were calculated based on RTOEGR dose rates, and those were varied from $0.181 \pm 0.007$ $\mathrm{mSv}$ to $0.295 \pm 0.007 \mathrm{mSv}$ with an average of $0.238 \pm 0.007 \mathrm{mSv}$. Excess Lifetime Cancer Risk (ELCR) on public health was estimated based on the annual effective dose. The Public's ELCR were from $0.720 \times 10^{-3}$ to $1.174 \times 10^{-3}$ with an average of $0.892 \times 10^{-3}$, which is higher than the worldwide standard value of $0.29 \times 10^{-3}$. The mean RTOEGR dose rate of the New Market Thana in Dhaka city is comparable to that of Sabzevar city (Iran), Kathmandu city of Tribhuvan University (Nepal), Baghdad city (Iraq), Kirikkale city (Turkey).
\end{abstract}

Keywords: Environment; Radiation; In-Situ; Public; ELCR.

() 2021 JSR Publications. ISSN: 2070-0237 (Print); 2070-0245 (Online). All rights reserved. doi: http://dx.doi.org/10.3329/jsr.v13i3.53112 J. Sci. Res. 13 (3), 879-890 (2021)

\section{Introduction}

People are exposed to natural sources of ionizing radiation continuously from the earth, construction materials, air, water, the universe. The presence of the naturally occurring radionuclides in the environment is the main contributor to the total effective dose received by the people. The greater part of public exposure to ionizing radiation contributes from natural radiation sources such as cosmic rays and terrestrial radiation [1]. High energy cosmic-rays depend on geological characteristics of a region, such as altitude, latitude, and lunar activity [2,3]. Natural radionuclides of terrestrial sources have very long half-lives or disintegrated from very long-lived primordial radionuclides (halflives on the order of $10^{9}-10^{10}$ years), and these radionuclides have been produced solar

\footnotetext{
*Corresponding author: msrahman1974@yahoo.com
} 
processes prior to the earth creation. The terrestrial background level dose is evaluated mainly from three primordial radionuclides such as ${ }^{40} \mathrm{~K},{ }^{238} \mathrm{U}$ and ${ }^{232} \mathrm{Th}$ and their decay products. These radionuclides are spread extensively and exist in nearly all geological materials in the earth's environment [4,5]. The deviation of terrestrial sources of ionizing radiation in a region is normally higher than that of cosmic rays [6]. Some regions in the world where the outdoor terrestrial sources of radiation level go beyond the worldwide mean value due to some radioactive minerals, and these regions identify as high background areas. The high background areas were found in some countries, namely Iran, India, China, Brazil, the USA, and Germany [7]. In addition to the natural sources of radiation, the background dose rates in a region were influenced by the anthropogenic radiation sources introduced into the environment through human activity [8]. Many radionuclides of the uranium decay products, thorium decay products, and potassium-40 (K-40) emit gamma-rays that contributed to public exposures in the outdoor environment. The gamma-rays are responsible for most external human exposures considering all types of ionizing radiation due to their high penetration capability [9]. Gamma-rays exist everywhere. Significant deviation has been reported to other countries [10-14] for gammaray dose rates in outdoor and indoor environments. Laboratory and In-Situ gamma spectroscopy methods are mainly used for environmental radiation monitoring and evaluation of activity concentration and dose rate in the outdoor environment for natural and anthropogenic radiation sources [15-20]. In the case of large-area environmental radiation monitoring, the $\mathrm{In}$-Situ method is more suitable than laboratory soil analysis due to its chances of cross-contamination in the laboratory and time-consuming. The consequences of low-level ionizing radiation exposures on public health are expected to be small, but it is not possible to eliminate the impact of the natural radionuclides in the environment. Low-level ionizing radiation exposure from the natural radionuclides during a long period may lead to some risks to public health [21]. The expression 'excess lifetime cancer risk' (ELCR) is defined as the probability of getting cancer for all people.

It is mentionable that there are few large \& old facilities situated in the New Market Thana, like New Market, Dhaka College, Bangladesh Council of Scientific and Industrial Research (BCSIR). New Market is the biggest and oldest shopping complex in Dhaka city. Many people used to visit New Market from all areas of Dhaka district and even outsides of Dhaka district for shopping along with their family members. Dhaka College is the oldest and largest college in Bangladesh. The New Market Thana is the busiest area in Dhaka city. The aim of the present study is to monitor the real-time radiation in the areas of New Market Thana, evaluate the annual effective dose to the public, and estimate the excess lifetime cancer risk (ELCR) on public health based on the annual effective dose.

\section{Materials and Methods}

\subsection{Equipment}


The RTOEGR dose rate was monitored using the DPRMD throughout the study. The DPRMD is equipped with a Geiger-Muller counter tube facilitating to detect not only gamma radiation but also alpha \& beta particles. The DPRMD is designed and manufactured by Germany, built with a solid Novadur exterior. An optional fashionable leather holster with a belt strap can extra protect the DPRMD from the elements. The DPRMD complies with all the requirements of European CE standards and the American FCC 15 standard. The DPRMD monitors radiation day and night and logs data for later download. Its battery lasts for years due to the sophisticated electronics. The data of the DPRMD can transfer to the PC through the USB port. The DPRMD stores all registered pulses in its internal memory and keeps those pulses ready to use when needed. The DPRMD features an acoustic signal that sounds when the dose rate exceeds a certain level. The default alert level is $5 \mu \mathrm{Sv} / \mathrm{h}$. The data of the DPRMD can be read and processed quickly and conveniently on a PC using the Toolbox software with Windows 7 and above version. The DPRMD has a battery pointer, several unit conversions, real-time dose rate, cumulative dose display functions, and programmable logging and alert functions. The DPRMD accurately monitors dose rate within the range of 0.01-5000 $\mu \mathrm{Sv} / \mathrm{h}$ (User Manual-GAMMA SCOUT, 2014).

\subsection{Calibration of the equipment}

The DPRMD was calibrated after construction by the Company (GmbH \& Co.KG, Germany). The DPRMD is calibrated every year using the standard gamma-ray sources like ${ }^{137} \mathrm{Cs}$, ${ }^{60} \mathrm{Co}$, and X-ray units from the Secondary Standard Dosimetry Laboratory (SSDL) under the Bangladesh Atomic Energy Commission (BAEC). The SSDL of BAEC has been available since 1991, which complies with the Primary Standard Dosimetry Laboratory (PSDL) of the National Physical Laboratory (NPL), United Kingdom. The SSDL of BAEC has an X-ray Unit $(30 \mathrm{kV}-225 \mathrm{kV})$ required to calibrate the radiation monitoring instruments. The SSDL of BAEC meets all the requirements of the International Atomic Energy Agency (IAEA)/World Health Organization (WHO) network of SSDLs. So, the RTOEGR dose rates of DPRMD comply with the international monitoring system.

\subsection{Description of the site and data collection procedure}

The New Market Thana area is 1.64 sq.km, and its location varies from $23^{\circ} 43^{\prime}-23^{\circ} 44^{\prime}$ north latitudes and $90^{\circ} 22^{\prime}-90^{\circ} 23^{\prime}$ east longitudes. Total population is 49,523 (male is 32685 and female is 16838) and population density is 30,197/sq.km [22]. The New Market Thana is the busiest area in Dhaka city because of different types of shopping centers like New Market, Gauchhia Market, Chandrima Super Market, Dhanmondi Hawkers Market, Katabon Market, Chadni Chawk Super Market, Anjana Plaza, Eastern Mallika, Multiplan Centre, Globe Shopping Complex, Badruddozza Shopping Centre, etc. People used to visit these shopping centers from other parts of Dhaka city and even outsides of Dhaka city for shopping. The map of the New Market Thana is shown in Fig. 
1 [23]. There are few large and old facilities in the New Market Thana, like New Market, Dhaka College, Bangladesh Council of Scientific and Industrial Research (BCSIR), Teacher Training College (TTC), etc. Thirty-two monitoring points (MP) were selected at the outdoor environment in New Market Thana to collect the RTOEGR dose rates following In-Situ Method. The MPs were identified using the GARMIN eTrex HC series personal navigator. The device has a reputable Garmin high-sensitivity GPS and the bestfeatured mapping to make an incomparable portable GPS receiver [24]. The GPS location data of the MPs were ranged from E: $90^{\circ} 22.980^{\prime}$ to E: $090^{\circ} 23.200^{\prime}$ and from N: $23^{\circ} 43.957^{\prime}$ to N: $23^{\circ} 44.626^{\prime}$. The RTOEGR dose rates monitoring were carried out from March-April 2019 using the DPRMD. Every MP, the DPRMD was placed at $1 \mathrm{~m}$ height above the ground on a tripod, and the time for gamma radiation monitoring was 1 hour. The dose rates and GPS reading of 32 MPs are shown in Table 1.

\subsection{Annual effective dose and ELCR calculation}

The outdoor $\&$ indoor occupancy factors of the public are 0.20 and 0.80 , respectively [25]. These occupancy factors are the fractions of a person's total time being exposed to a radiation field outdoor and indoor. The annual effective dose to the public in the outdoor environment due to radiation is calculated using the equation below:

$$
\text { Annual effective dose }(\mu \mathrm{Sv})=\text { dose rate }\left(\mu \mathrm{Sv} \cdot \mathrm{h}^{-1}\right) \times 0.2 \times 8760 \mathrm{~h} . \mathrm{yr}^{-1}(1)
$$

Excess lifetime cancer risk (ELCR) on public health is calculated based on the annual effective dose using the equation below:

$$
E L C R=A E D \times D L \times R F
$$

Where AED is the annual effective dose to the public, DL is the duration of life of Bangladeshi people [26], and RF is the risk factor $\left(\mathrm{Sv}^{-1}\right)$ which is the fatal cancer risk per sievert. RF is considered a fatal cancer risk per sievert. The probability of getting the stochastic effects on the public health if public receives low-level ionizing radiation during a long time from the environment, International Commission on Radiological Protection (ICRP) suggested the value of RF is 0.057 [27] for the public, and Biological Effects of Ionizing Radiation (BEIR) suggested the value of RF is 0.064 [28] for the public. 


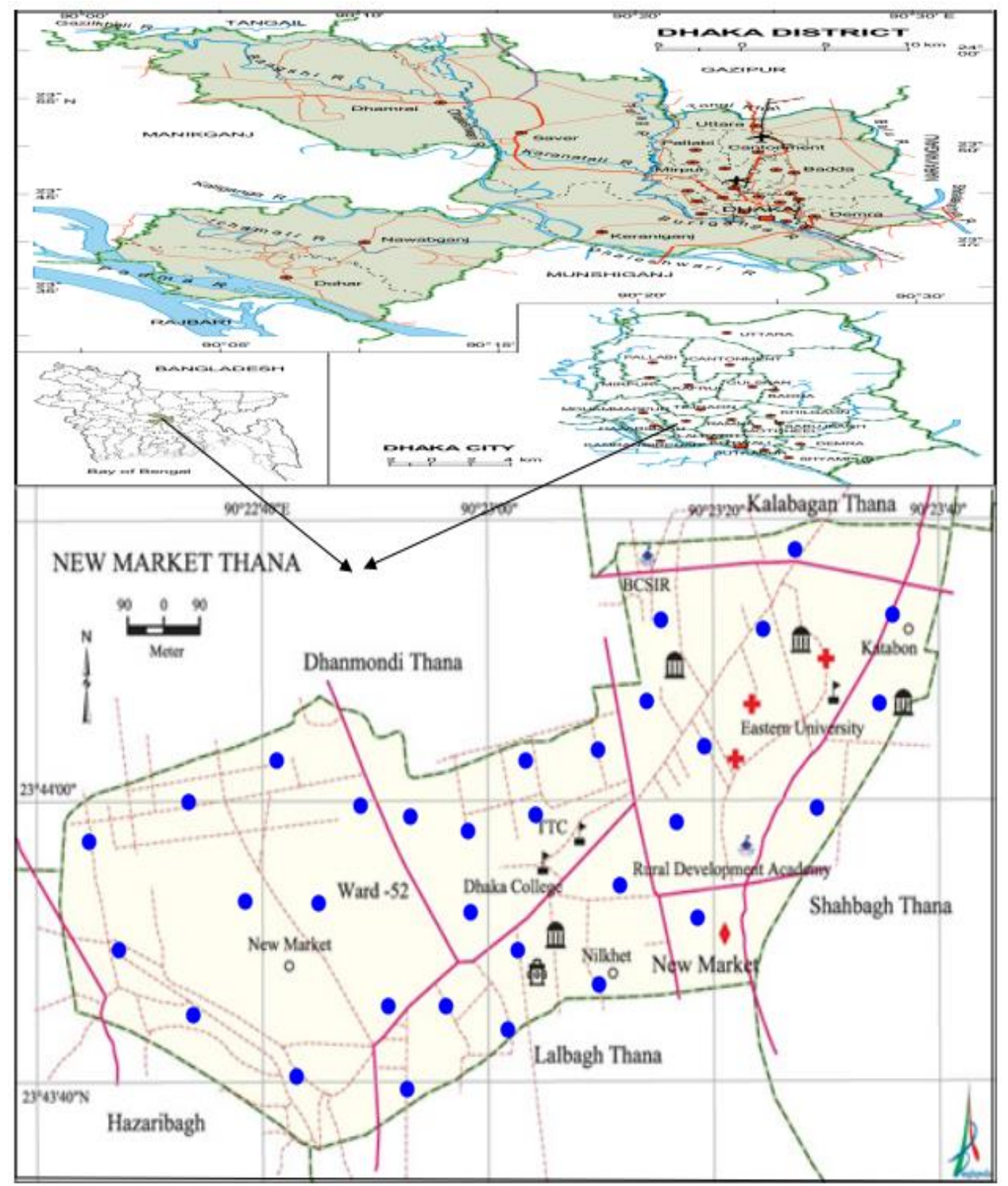

Fig. 1. Shows the MPs $(\bullet)$ of the New Market Thana in Dhaka city using the DPRMD.

\section{Results and Discussion}

\subsection{Collection of outdoor gamma-ray dose rate}

It was observed that the dose rate in 32 MPs at New Market Thana in Dhaka city contributed to the natural radionuclides existing in the earth's crust and cosmic rays. 


\subsection{Dose rate and annual effective dose}

The RTOEGR dose rate of 32 MPs of the New Market Thana in Dhaka city was ranged from $0.103 \pm 0.004 \mu \mathrm{Sv} / \mathrm{h}$ to $0.168 \pm 0.007 \mu \mathrm{Sv} / \mathrm{h}$ with an average of $0.135 \pm 0.004 \mu \mathrm{Sv} / \mathrm{h}$. The annual effective doses to the public were calculated based on the RTOEGR dose rates, and those were varied from $0.181 \pm 0.007 \mathrm{mSv}$ to $0.295 \pm 0.007 \mathrm{mSv}$ with an average of $0.238 \pm 0.007 \mathrm{mSv}$. Table 1 shows the dose rate range, mean, and the annual effective dose to the public for each MP. Large variations of the RTOEGR dose rates were observed at different MPs depicted in Table 1. The variation of the RTOEGR dose rates might be created by the geological characteristics of the locations. The highest and the lowest RTOEGR dose rates were found to be $0.168 \pm 0.004 \mu \mathrm{Sv} / \mathrm{h}$ and $0.103 \pm$ $0.004 \mu \mathrm{Sv} / \mathrm{h}$ in the Eastern University (3) and the Nilkhet (1), respectively. A higher value of the RTOEGR dose rate in the Eastern University (3) MP is the contribution of the construction materials of the buildings. On the other hand, the lower value of the RTOEGR dose rate in the Nilkhet (1) MP is due to the lack of construction materials of the buildings. The mean RTOEGR dose rate of the New Market Thana is lower than Ramna Thana in Dhaka city [29] and Shahbag Thana in Dhaka city [30]. The lower value of the mean RTOEGR dose rate of the New Market Thana compared to that of the other two Thanas in Dhaka city might be due to the lack of large hospitals and radiological facilities where radioactive substances are handling.

Table 1. The dose rates and calculated annual effective dose to the public at New Market Thana in Dhaka city.

\begin{tabular}{|c|c|c|c|c|c|c|}
\hline \multirow{2}{*}{$\begin{array}{l}\text { MP } \\
\text { No. }\end{array}$} & \multirow{2}{*}{ Name of location } & \multirow{2}{*}{$\begin{array}{l}\text { Latitude/ } \\
\text { Altitude }\end{array}$} & \multicolumn{3}{|c|}{$\begin{array}{l}\text { Gamma radiation dose rate } \\
\left(\mu \mathrm{Sv} \cdot \mathrm{h}^{-1}\right)\end{array}$} & \multirow{2}{*}{$\begin{array}{l}\text { Mean annual } \\
\text { effective dose due } \\
\text { to gamma radiation } \\
(\mathrm{mSv}) \pm \mathrm{SD}\end{array}$} \\
\hline & & & Range & Mean & $\mathrm{SD}$ & \\
\hline 1 & New Market (1) & $\begin{array}{l}\mathrm{N} 23^{\circ} 44.059 \\
' \mathrm{E} 90^{\circ} 23.035\end{array}$ & $(0.124-0.136)$ & 0.131 & 0.003 & $0.229 \pm 0.006$ \\
\hline 2 & New Market (2) & $\begin{array}{l}\mathrm{N} 23^{\circ} 44.009 \\
' \mathrm{E} 90^{\circ} 23.061\end{array}$ & $(0.127-0.139)$ & 0.133 & 0.004 & $0.232 \pm 0.007$ \\
\hline 3 & New Market (3) & $\begin{array}{l}\mathrm{N} 23^{\circ} 44.001 \\
\mathrm{E} 90^{\circ} 23.088^{\prime}\end{array}$ & $(0.139-0.152)$ & 0.145 & 0.004 & $0.253 \pm 0.006$ \\
\hline 4 & New Market (4) & $\begin{array}{l}\mathrm{N} 23^{\circ} 43.960 \\
\mathrm{E} 90^{\circ} 23.070\end{array}$ & $(0.124-0.140)$ & 0.130 & 0.005 & $0.227 \pm 0.009$ \\
\hline 5 & New Market (5) & $\begin{array}{l}\mathrm{N} 23^{\circ} 43.942 \\
' \mathrm{E} 90^{\circ} 23.026\end{array}$ & $(0.092-0.118)$ & 0.103 & 0.009 & $0.181 \pm 0.016$ \\
\hline 6 & New Market (6) & $\begin{array}{l}\mathrm{N} 23^{\circ} 43.984 \\
' \mathrm{E} 90^{\circ} 23.051\end{array}$ & $(0.105-0.129)$ & 0.117 & 0.007 & $0.205 \pm 0.010$ \\
\hline 7 & Ward-52 (1) & $\begin{array}{l}\mathrm{N} 23^{\circ} 44.047 \\
' \mathrm{E} 90^{\circ} 23.012\end{array}$ & $(0.118-0.130)$ & 0.124 & 0.004 & $0.216 \pm 0.007$ \\
\hline 8 & Ward-52 (2) & $\begin{array}{l}\mathrm{N} 23^{\circ} 44.073 \\
' \mathrm{E} 90^{\circ} 23.016\end{array}$ & $(0.134-0.145)$ & 0.139 & 0.003 & $0.244 \pm 0.006$ \\
\hline 9 & Ward-52 (3) & $\begin{array}{l}\mathrm{N} 23^{\circ} 44.086 \\
' \mathrm{E} 90^{\circ} 23.070\end{array}$ & $(0.090-0.120)$ & 0.105 & 0.011 & $0.184 \pm 0.019$ \\
\hline 10 & Ward-52 (4) & $\begin{array}{l}\mathrm{N} 23^{\circ} 44.051 \\
' \mathrm{E} 90^{\circ} 23.029\end{array}$ & $(0.120-0.145)$ & 0.134 & 0.007 & $0.235 \pm 0.012$ \\
\hline
\end{tabular}




\begin{tabular}{|c|c|c|c|c|c|c|}
\hline & Nilkhet (1) & $\begin{array}{l}\mathrm{N} 23^{\circ} 43.958 \\
\mathrm{E} 90^{\circ} 23.142^{\prime}\end{array}$ & $(0.096-0.109)$ & 0.103 & 0.004 & $0.181 \pm 0.007$ \\
\hline 12 & Nilkhet (2) & $\begin{array}{l}\mathrm{N} 23^{\circ} 43.957 \\
\mathrm{E} 90^{\circ} 23.200^{\prime}\end{array}$ & $(0.112-0.125)$ & 0.117 & 0.004 & $0.205 \pm 0.007$ \\
\hline 13 & Nilkhet (3) & $\begin{array}{l}\mathrm{N} 23^{\circ} 44.987 \\
\text { 'E90 } 23.121\end{array}$ & $(0.086-0.120)$ & 0.104 & 0.009 & $0.182 \pm 0.015$ \\
\hline 14 & Nilkhet (4) & $\begin{array}{l}\mathrm{N} 23^{\circ} 44.993 \\
\text { 'E90 } 23.119\end{array}$ & $(0.115-0.134)$ & 0.124 & 0.006 & $0.217 \pm 0.011$ \\
\hline 15 & Nilkhet (5) & $\begin{array}{l}\mathrm{N} 23^{\circ} 44.984 \\
{ }^{\prime} \mathrm{E} 90^{\circ} 23.101\end{array}$ & $(0.101-0.110)$ & 0.106 & 0.003 & $0.185 \pm 0.005$ \\
\hline 16 & Nilkhet (6) & $\begin{array}{l}\mathrm{N} 23^{\circ} 44.120 \\
{ }^{\prime} \mathrm{E} 90^{\circ} 23.037\end{array}$ & $(0.126-0.145)$ & 0.135 & 0.006 & $0.236 \pm 0.011$ \\
\hline 17 & Dhaka College (1) & $\begin{array}{l}\mathrm{N} 23^{\circ} 44.112 \\
{ }^{\prime} \mathrm{E} 90^{\circ} 23.006\end{array}$ & $(0.132-0.145)$ & 0.139 & 0.004 & $0.244 \pm 0.007$ \\
\hline 18 & Dhaka College (2) & $\begin{array}{l}\mathrm{N} 23^{\circ} 44.158 \\
\text { 'E90⒉ } 22.991\end{array}$ & $(0.116-0.125)$ & 0.120 & 0.003 & $0.211 \pm 0.005$ \\
\hline 19 & Dhaka College (3) & $\begin{array}{l}\mathrm{N} 23^{\circ} 44.195 \\
{ }^{\prime} \mathrm{E} 90^{\circ} 23.020\end{array}$ & $(0.115-0.128)$ & 0.122 & 0.004 & $0.213 \pm 0.007$ \\
\hline 20 & TTC (1) & $\begin{array}{l}\mathrm{N} 23^{\circ} 44.199 \\
\text { 'E90²2.980 }\end{array}$ & $(0.122-0.139)$ & 0.128 & 0.005 & $0.224 \pm 0.008$ \\
\hline 21 & TTC (2) & $\begin{array}{l}\mathrm{N} 23^{\circ} 44.180 \\
{ }^{\prime} \mathrm{E} 90^{\circ} 23.013\end{array}$ & $(0.052-0.150)$ & 0.121 & 0.028 & $0.212 \pm 0.049$ \\
\hline 22 & TTC (3) & $\begin{array}{l}\mathrm{N} 23^{\circ} 44.173 \\
\text { 'E90²3.066 }\end{array}$ & $(0.133-0.145)$ & 0.138 & 0.004 & $0.242 \pm 0.006$ \\
\hline 23 & $\begin{array}{l}\text { Rural Development } \\
\text { Academy (1) }\end{array}$ & $\begin{array}{l}\mathrm{N} 23^{\circ} 44.154 \\
{ }^{\prime} \mathrm{E} 90^{\circ} 23.032\end{array}$ & $(0.128-0.170)$ & 0.141 & 0.015 & $0.246 \pm 0.025$ \\
\hline 24 & $\begin{array}{l}\text { Rural Devel } \\
\text { Academy (2 }\end{array}$ & $\begin{array}{l}\mathrm{N} 23^{\circ} 44.148 \\
{ }^{\prime} \mathrm{E} 90^{\circ} 23.056\end{array}$ & $(0.097-0.197)$ & 0.149 & 0.031 & $0.261 \pm 0.054$ \\
\hline 25 & $\begin{array}{l}\text { Rural Development } \\
\text { Academy (3) }\end{array}$ & $\begin{array}{l}\mathrm{N} 23^{\circ} 44.331 \\
\text { 'E90 } 23.397\end{array}$ & $(0.120-0.136)$ & 0.129 & 0.005 & $0.225 \pm 0.008$ \\
\hline 26 & Eastern University (1) & $\begin{array}{l}\mathrm{N} 23^{\circ} 44.537 \\
{ }^{\prime} \mathrm{E} 90^{\circ} 23.844\end{array}$ & $(0.143-0.165)$ & 0.159 & 0.006 & $0.277 \pm 0.010$ \\
\hline 27 & Eastern University (2) & $\begin{array}{l}\mathrm{N} 23^{\circ} 44.626 \\
\text { 'E90 } 23.816\end{array}$ & $(0.161-0.175)$ & 0.168 & 0.004 & $0.295 \pm 0.007$ \\
\hline 28 & Katabon (1) & $\begin{array}{l}\mathrm{N} 23^{\circ} 44.331 \\
{ }^{\prime} \mathrm{E} 90^{\circ} 23.397\end{array}$ & $(0.100-0.120)$ & 0.108 & 0.006 & $0.188 \pm 0.010$ \\
\hline 29 & Katabon (2) & $\begin{array}{l}\mathrm{N} 23^{\circ} 44.334 \\
{ }^{\prime} \mathrm{E} 90^{\circ} 23.435\end{array}$ & $(0.125-0.134)$ & 0.130 & 0.003 & $0.226 \pm 0.005$ \\
\hline 30 & BCSIR (1) & $\begin{array}{l}\mathrm{N} 23^{\circ} 44.374 \\
\text { 'E90 } 23.005\end{array}$ & $(0.098-0.113)$ & 0.106 & 0.004 & $0.185 \pm 0.007$ \\
\hline 31 & BCSIR (2) & $\begin{array}{l}\mathrm{N} 23^{\circ} 44.344 \\
{ }^{\prime} \mathrm{E} 90^{\circ} 23.004\end{array}$ & $(0.103-0.130)$ & 0.114 & 0.008 & $0.199 \pm 0.015$ \\
\hline 32 & BCSIR (3) & $\begin{array}{l}\mathrm{N} 23^{\circ} 44.335 \\
\mathrm{E} 90^{\circ} 23.093^{\prime}\end{array}$ & $(0.125-0.135)$ & 0.130 & 0.003 & $0.227 \pm 0.005$ \\
\hline
\end{tabular}




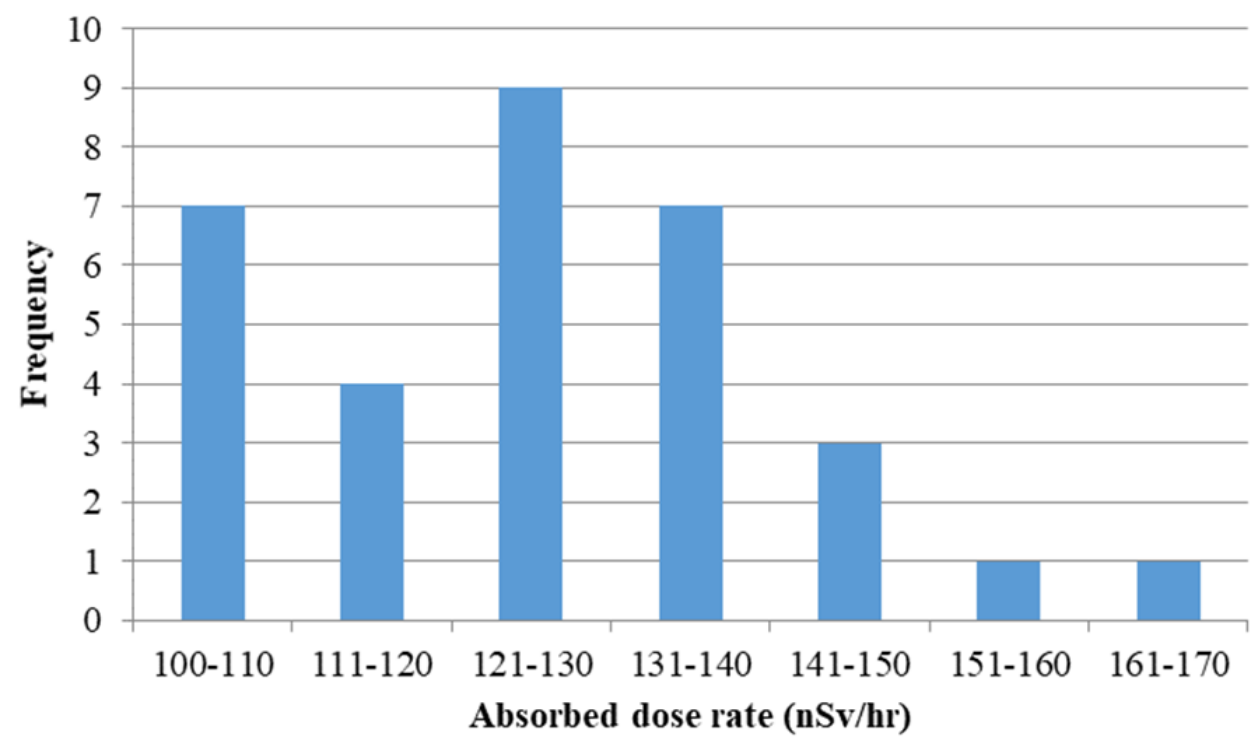

Fig. 2. Frequency distribution of the absorbed dose rate $\left(\mathrm{nSv} \cdot \mathrm{hr}^{-1}\right)$ at New Market Thana in Dhaka city.

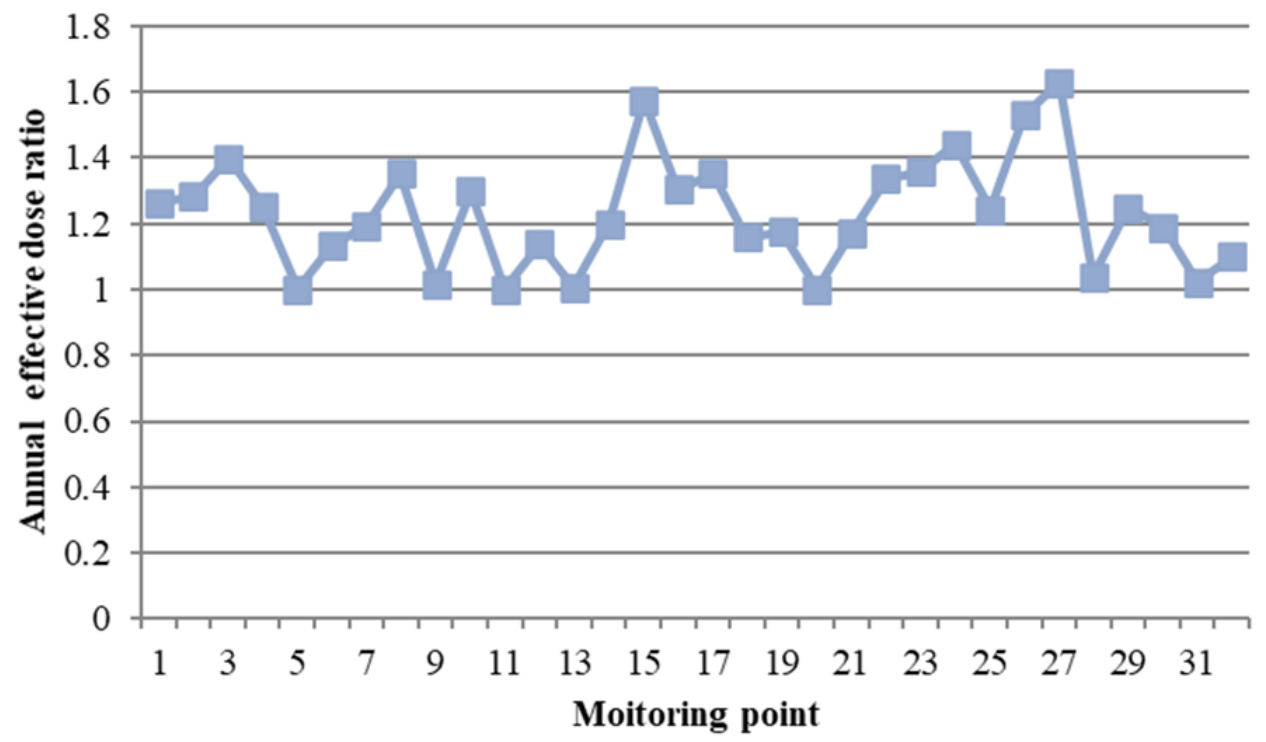

Fig. 3. Outdoor annual effective dose values normalized to the minimum annual effective dose for each MP.

The ELCR on public health was estimated based on the annual effective dose. The ELCR on public health was varied from $7.2 \times 10^{-4}$ to $1.174 \times 10^{-3}$ with an average of $8.92 \times 10^{-4}$ as per ICRP recommendation [27]. The ELCR on public health was varied from 
$8.09 \times 10^{-4}$ to $1.318 \times 10^{-3}$ with an average of $1.002 \times 10^{-3}$ as per BEIR recommendation [28]. The average ELCR on public health at New Market Thana is 3 times higher than that of the worldwide average of $0.29 \times 10^{-3}$ [58].

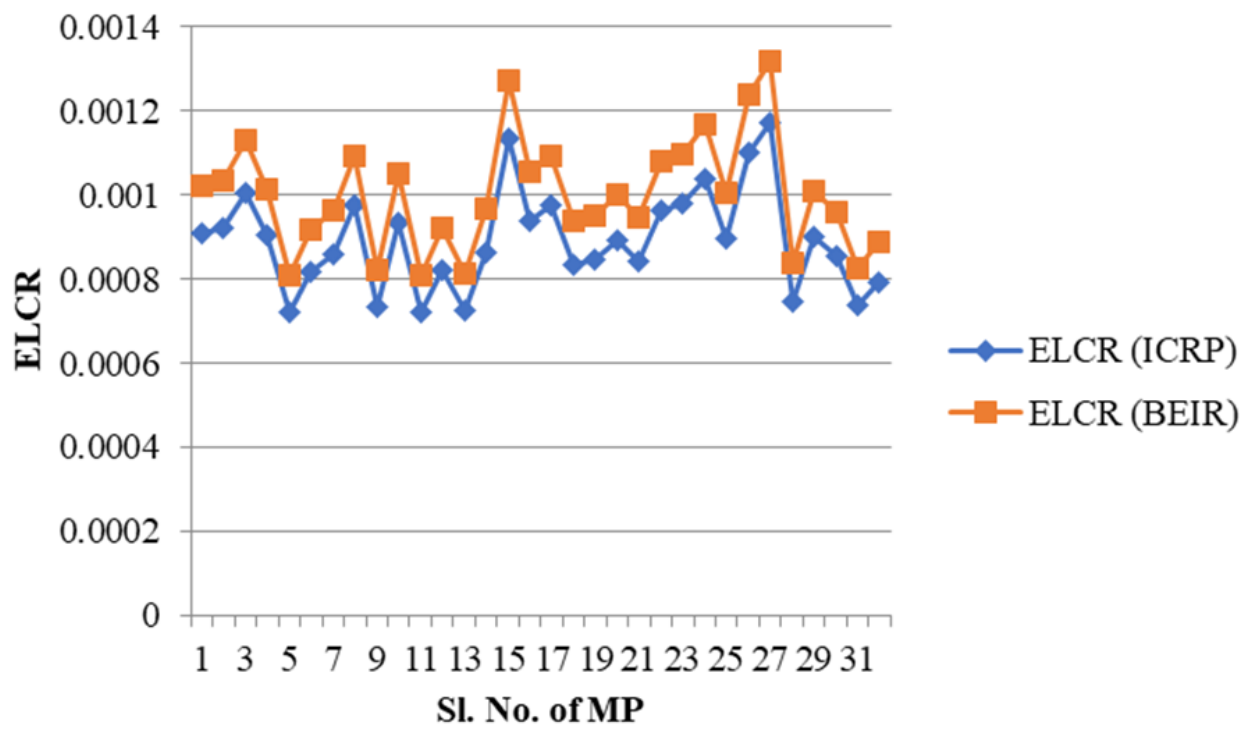

Fig. 4. Excess lifetime cancer risk (ELCR) on public health based on ICRP and BEIR recommendations.

From Table 2, it was observed that the mean RTOEGR dose rate of the New Market Thana in Dhaka city is lower than that of Iran, Chad, Nigeria, Turkey and higher than that of Egypt, India, Pakistan, Iraq. Furthermore, the mean RTOEGR dose rate of the New Market Thana in Dhaka city is comparable to that of Sabzevar city, Iran [38], Tribhuvan University, Nepal [43], Baghdad city, Iraq [54], Kirikkale city, Turkey [57].

Table 2. Comparison of outdoor dose rate, annual effective dose and ELCR values of New Market Thana, Dhaka, Bangladesh with other countries.

\begin{tabular}{lllll}
\hline Country & $\begin{array}{l}\text { Dose rate } \\
\text { Range(mean) in } \\
\mu \text { Sv/h }\end{array}$ & $\begin{array}{l}\text { Annual effective } \\
\text { dose range (mean) } \\
\text { in mSv }\end{array}$ & $\begin{array}{l}\text { ELCR range (mean) } \\
\text { X10 }\end{array}$ & Reference \\
\hline Iran & $0.429-0.781(0.605)$ & $0.527-0.958(0.74)$ & 2.956 & 31 \\
Chad & - & $0.028-1.807(0.255)$ & $0.058-3.794(0.535)$ & 32 \\
Egypt & $0.07-0.22(0.16)$ & $0.07-0.25(0.16)$ & $0.23-0.88(0.56)$ & 33 \\
India & $0.03-0.198(0.106)$ & $0.04-0.242(0.072)$ & $0.15-0.85(0.25)$ & 34 \\
India & $0.21-1.34(0.106)$ & $0.29-4.22$ & $1.18-14.12$ & 35 \\
Iran & $0.034-0.090$ & $0.16-0.44$ & $0.81-1.3$ & 36 \\
Pakistan & $0.038-0.175(0.087)$ & $0.05-0.21(0.11)$ & $0.61-0.75(0.37)$ & 37 \\
Iran & $0.066-0.198(0.134)$ & 0.85 & 3.39 & 38 \\
Iraq & $0.026-0.084(0.050)$ & $0.03-0.10(0.06)$ & $0.11-0.34(0.20)$ & 39 \\
Pakistan & $0.056-0.148(0.105)$ & 0.928 & $0.352-0.792(0.543)$ & 40 \\
Jamaica & $0.008-0.230$ & 0.557 & $0.0016-0.792(0.163)$ & 41 \\
\hline
\end{tabular}




\begin{tabular}{lllll}
\hline Morocco & $0.009-0.091$ & $0.05-0.56$ & $0.19-1.96$ & 42 \\
Nepal & $0.077-0.205(0.115)$ & 0.142 & 0.536 & 43 \\
Nigeria & $0.122-0.278(0.203)$ & 0.311 & 0.81 & 44 \\
Palestine & $0.011-0.083(0.035)$ & $0.014-0.101(0.044)$ & $0.70-1.33(0.95)$ & 45 \\
Saudi Arabia & $0.018-0.055(0.035)$ & 0.37 & $0.07-0.24(0.20)$ & 46 \\
Tanzania & $0.026-0.386$ & $0.03-0.47$ & $0.11-1.70$ & 47 \\
Turkey & $0.021-0.826(0.205)$ & $0.026-1.013(0.252)$ & 1.0 & 48 \\
Nigeria & $0.147-0.228$ & $0.183-0.419(0.268)$ & - & 49 \\
Nigeria & $0.120-0.234$ & $0.23-0.36$ & $0.37-3.70(1.26)$ & 50 \\
Nigeria & $0.112-0.143$ & $0.119-0.153$ & $0.418-0.534$ & 51 \\
Nigeria & $0.15-0.33(0.23)$ & $1.46-2.92$ & $4.59-10.22$ & 52 \\
Pakistan & $0.189-0.269(0.220)$ & $0.30-0.50(0.40)$ & $1.20-1.60(1.40)$ & 53 \\
Iraq & $0.080-0.150(0.111)$ & $0.113-0.159(0.136)$ & - & 54 \\
India & $0.081-0.144$ & $0.10-0.18$ & $0.375-0.662$ & 55 \\
Switzerland & $0.058-0.107$ & $0.63-0.96(0.79)$ & - & 56 \\
Turkey & $0.023-0.320(0.121)$ & $0.04-0.59(0.23)$ & $0.14-2.07(0.80)$ & 57 \\
Worldwide & 0.059 & 0.07 & 0.29 & $58,34,31$ \\
average & & & & \\
Bangladesh & $0.103-0.168(0.135)$ & $0.28-0.67(0.43)$ & $0.72-1.174(0.892)$ & This study \\
\hline
\end{tabular}

\section{Conclusion}

The monitoring of the RTOEGR dose rate is very necessary for the radiological mapping of a nuclear newcomer country like Bangladesh. The radiological mapping is required to know the deviation of the RTOEGR dose rate before and after operation of the Rooppur Nuclear Power Plant Project of Bangladesh and calculate the public exposure that contributes from the nuclear facility. The mean RTOEGR dose rate of the New Market Thana in Dhaka city is comparable to that of Sabzevar city (Iran), Kathmandu city of Tribhuvan University (Nepal), Baghdad city (Iraq), Kirikkale city (Turkey).

\section{Acknowledgment}

This research is funded by the Ministry of Science and Technology, Government of Bangladesh under the Special Research Allocation Project 2019-2020 \& 2020-2021 (the grant serial number 523 MS \& 519 MS).

\section{Reference}

1. M. Charles, J. Radiol. Prot. 21, 83 (2001). https://doi.org/10.1088/0952-4746/21/1/609

2. Agency for Toxic Substances and Disease Registry (ATSDR) Toxicological Profile for Ionizing Radiation (Atlanta, GA: US, Department of Health and Human Services, Public Health Service, 1999).

3. UNSCEAR Report, Sources and Effects of Ionizing Radiation, Annex A: Dose Assessment Methodologies (New York, United Nations Scientific Committee on the effects of atomic radiation, 2000) vol. 1.

4. S. Selvasekarapandian, K. S. Lakshmi, G. M. Brahmanandhan, and V. Meenakshisundaram, Int. Congr. Ser. 1276, 327 (2005). https://doi.org/10.1016/j.ics.2004.10.026

5. W. F. Wilson, A Guide to Naturally Occurring Radioactive Materials (Oklahoma, PennWell Books, 1994) pp.128. 
6. N. Karunakara, I. Yashodhara, K. K. Sudeep, R. M. Tripathi, S. N. Menon, and M. P. Chougaonkar, Results Phys. 4, 20 (2014). https://doi.org/10.1016/j.rinp.2014.02.001

7. United Nations Scientific Committee on the Effects of Atomic Radiation, Report to the General Assembly. Sources and Effects of Ionizing Radiation, Annex B: Exposures of the Public and Workers from Various Sources of Radiation (New York, 2008) vol. 1.

8. S. Hazrati, S. Harrad, M. Alighadri, H. Sadeghi, A. Mokhtari, N. Gharari, and S. Rahimzadeh, Iran. J. Environ. Health Sci. Eng. 7, 157 (2010).

9. F. S. Al-Saleh, Appl. Radiat. Isot. 65, 843 (2007). https://doi.org/10.1016/j.apradiso.2007.01.021

10. F. H. Al-Ghorable, Environ. Res. 98, 160 (2005). https://doi.org/10.1016/j.envres.2004.06.004

11. H. Arvela, Int. Congr. Ser. 1225, 9 (2002). https://doi.org/10.1016/S0531-5131(01)00532-5

12. L. Rybach, D. Bachler, B. Bucher, and G. Schwarz, J. Environ. Radiat. 62, 277 (2002). https://doi.org/10.1016/S0265-931X(01)00169-2

13. F. Sagnatchi, M. Salouti, and A. Eslami, Radiat. Prot. Dosim. 132, 346 (2008). https://doi.org/10.1093/rpd/ncn285

14. M. B. Tavakoli, Med. Sci. Monit. 9, 7 (2003).

15. H. L. Beck, J. D. Campo, and C. Gogolak, In-Situ Ge(Li) and NaI(Tl) Gamma-ray Spectrometry (Environmental measurement Lab., HASL-258, New York, US DOE, 1972).

16. I. Nikl and L. B. Sztanyik, Radiat. Prot. Dosim. 24, 387 (1998). https://doi.org/10.1093/rpd/24.1-4.387

17. International Commission on Radiation Units and Measurements, ICRU Report 53: Gammaray Spectrometry in the Environment (Bethesda, MD 20814-3095, USA, 1994).

18. I. Othman and T. Yassine, Sci. of Tot. Environ. 170, 119 (1995). https://doi.org/10.1016/0048-9697(95)04610-D

19. M. Tzortzis, H. Tsertos, S. Christofides, and G. Christodoulides, Radiat. Measur. 37, 221 (2003). https://doi.org/10.1016/S1350-4487(03)00028-3

20. X. S. Clouvas and M. Antonopoulos-Domis, Radiat. Prot. Dosim. 112(2), 267 (2004).

21. Environmental Protection Agency, Exposure Factors Handbook (Edition EPA/600/R-09/052F, US Environmental Protection Agency, 2011).

22. Bangladesh Population Census (Bangladesh Bureau of Statistics, 2011).

23. https://www.banglapedia.org/, accessed: 20 September 2020

24. Owner's Manual GARMIN eTrex HC Series (Kansas, USA, 2007). https://static.garmincdn.com/pumac/eTrexLegendHCx_OwnersManual.pdf

25. United Nations Scientific Committee on the Effects of Atomic Radiation, Sources, Effects and Risks of Ionizing Radiation (United Nations, New York, 1988). https://www.unscear.org/

26. http://en.worldstat.info/Asia/Bangladesh, accessed: 21 September 2020.

27. ICRP, Recommendations of the ICRP Publication103: Annals of the ICRP, International Commission on Radiological Protection, 37 (Ottawa, Ontario, Canada, 2007) pp. 2-4. https://www.icrp.org/page.asp?id=7

28. National Academy of Sciences, National Research Council Committee to Assess Health Risks from Exposure to Low-levels of Ionizing Radiation (BEIR VII, 2006).

29. M. S. Mian, M. S. Rahman, J. Islam, K. N. Sakib, M. M. Tasnim, and S. Yeasmin, J. Sci. Res. 11, 263 (2019). doi: http://dx.doi.org/10.3329/jsr.v11i3.39318

30. S. Tazmin, M. S. Rahman, S. Yeasmin, and M. H. Ahsan, M. Mahfuzzaman, Int. J. Sci. Res. Manag. 6, 58 (2018). https://doi.org/10.3329/jsr.v11i3.39318

31. A. Eslami, A. Shahsavani, M. H. Saghi, L. Akhoondi, and A. Goorani, J. Air Pollut. Health 1, 243 (2016).

32. S. Penabei, D. Bongue, P. Maleka, T. Dlamini, Saidou, C. J. G. Shouop, Y. I. Halawlaw, A. N. Ebongue, and M. G. K. Njock, Radioprotection 53, 265 (2018). https://doi.org/10.1051/radiopro/2018030

33. S. Fares, A. K. Hassan, H. I. El-Saeedy, B. Alshahrani, and H. Yakout, ChemXpress 10, 119 (2017). 
34. S. Murugesan, S. Mullainathan, V. Ramasamy, and V. Meenakshisundaram, J. Mater. Environ. Sci. 7, 2375 (2016).

35. S. Monica, A. K. V. Prasad, S. R. Soniya, and P. J. Jojo, Radiat. Prot. Environ. 39, 38 (2016). https://doi.org/10.4103/0972-0464.185180

36. M. Haghparast, M. A. Ardekani, M. Navaser, S. Refahi, M. Najafzadeh, H. Ghaffari, and M. Masoumbeigi, Med. J. Islam. Repub. Iran 34, 56 (2020).

37. A. A. Qureshi , S. Tariq, K. U. Din , S. Manzoor, C. Calligaris, and A. Waheed, J. Radiat. Res. Appl. Sci. 7, 438 (2014). https://doi.org/10.1016/j.jrras.2014.07.008

38. A. Eslami, M. H. Saghi, and A. Rastegar, Tehran Univ. Med. J. 73, 751 (2016).

39. R. S. Mohammed and R. S. Ahmed, Environ. Earth. Sci. 76, 303 (2017). https://doi.org/10.1007/s12665-017-6616-7

40. M. Rafique, S. Rahman, M. Basharat, W. Aziz, I. Ahmad, K. A. Lone, and K. Ahmad Matiullah, J. Radiat. Res. Appl. Sci. 7, 29 (2014). https://doi.org/10.1016/j.jrras.2013.11.005

41. M. O. Miller and M. Voutchkov, Air Qual. Atmos. Health, 9, 551 (2016). https://doi.org/10.1007/s11869-015-0360-5

42. B. Kassi, A. Boukhair, K. Azkour, M. Fahad, M. Benjelloun, and A. M. Nourreddine, World J. Nucl. Sci. Technol. 8, 176 (2018). https://doi.org/10.4236/wjnst.2018.84015

43. A. Mishra and R. Khanal, Him. Phy. 8, 47 (2019). https://doi.org/10.3126/hp.v8i0.30001

44. U. L. Anekwe and R. A. Onoja, J. Appl. Sci. Environ. Manag. 24, 1045 (2020). https://doi.org/10.4314/jasem.v24i6.16

45. K. M. Thabayneh and M. M. Jazzar, Open J. Soil Sci. 2 , 7 (2012). https://doi.org/10.4236/ojss.2012.21002

46. A. El-Taher and J. H. Al-Zahrani, Ind. J. Pure Appl. Phys. 52, 147 (2014).

47. L. L. Nkuba and P. B. Nyanda, Braz. J. Rad. Sci. 5, 01 (2017). https://doi.org/10.15392/bjrs.v5i3.306

48. A. Kurnaz, Radiat. Prot. Dosim. nct115 (2013). https://doi.org/10.1093/rpd/nct115

49. S. B. Ibikunle, Environ. Foren. 21, 113 (2020). https://doi.org/10.1080/15275922.2020.1728430

50. G. O. Avwiri, J. Ekpo, and Y. E. Chad-Umoren, Asian Phys. Chem. Sci. 7, 1 (2019). https://doi.org/10.9734/ajopacs/2019/v7i430099

51. I. D. Benson and F.O. Ugbede, IOSR-JAP, 10, 77 (2018).

52. U. L. Anekwe and P. I. Enyinna, Int. J. Adv. Res. Phys. Sci. 4, 57 (2017).

53. M. Ali, S. Bano, J. A. Qureshi, M. Wasim, G. Khan, F. Begum, and M. Alam, J. Himal. Earth Sci. 52, 177 (2019).

54. R. K. Ahmed, J. Kufa, Phys. 4, 48 (2012).

55. P. Sharma, P. K. Meher, and K. P. Mishra, J. Rad. Res. Appl. Sci. 7, 595 (2014). https://doi.org/10.1016/j.jrras.2014.09.011

56. M. Boucher, External Background Radiation in the Fribourg (Switzerland) Urban Area (Departement de Physique, Universite de Fribourg, Suisse, 2008).

57. N. Bingoldag and P. Otansev, Radiochim. Acta 106, 401 (2018). https://doi.org/10.1515/ract-2017-2781

58. United Nations Scientific Committee on the Effects of Atomic Radiation, Report to the General Assembly "Sources and Effects of Ionizing Radiation," Annex A: Dose Assessment Methodologies (New York, USA, 2000) 1. 